\section{Biotechnologies to advance health in developing countries ${ }^{1}$}

Key words: biotechnology, genomics, communicable diseases, health policy, developing countries, international cooperation.

\footnotetext{
1 Based on: 1) University of Toronto Joint Centre for Bioethics. Top 10 biotechnologies for improving health in developing countries. Toronto, Ontario, Canada: University of Toronto Joint Centre for Bioethics; 2002. Available from: http:/ / www.utoronto.ca/jcb [Internet site]. Accessed 10 December 2002. 2) University of Toronto Joint Centre for Bioethics. Experts rank top 10 biotechnologies for improving global health within 5-10 years [news release]. Toronto, Ontario, Canada: University of Toronto Joint Centre for Bioethics; 2002. Available from: http://www.utoronto.ca/jcb [Internet site]. Accessed 10 December 2002.
}

Millions of people in developing countries now die each year from diseases that in the near future could be prevented or treated cheaply and easily through the development and use of such biotechnologies as genetically engineered vaccines and new procedures that enable faster, more-accurate, and moreaffordable diagnosis of infectious diseases, according to a study released recently by a research center in Canada. The study also says biotechnology advances could increase the length and quality of life of more than a billion people around the who have been left largely untouched by many of the health advances that benefited the developed countries of the world in the 20th century.

The study was conducted by researchers at the University of Toronto's Joint Centre for Bioethics (JCB). Based in Toronto, Ontario, Canada, the JCB is a partnership among the University of Toronto and eight affiliated hospitals. The JCB focuses on research, education, and clinical activities related to bioethics.

Entitled Top 10 Biotechnologies for Improving Health in Developing Countries, the study identifies 10 of the genomic biotechnologies and other biotechnologies most likely to improve global health within a decade. To prepare the study and identify the most-promising biotechnologies, the JCB researchers worked with a panel of 28 experts on genome-related technology and global health issues from around the world. Panelists from the Region of the Americas included specialists from Brazil, Canada, Cuba, Mexico, and the United States of America.

The 28 panelists used a three-round process over a five-month period in selecting the 10 biotechnologies. The experts first responded to an openended question asking them to suggest promising areas of plant, animal, or human genomics or other biotechnologies that could be relevant to either communicable or noncommunicable diseases in developing countries. The technologies could be predictive, preventive, diagnostic, or therapeutic ones and could also be convergent between health and agricultural biotechnology. The second and third rounds of discussion were used to narrow down the initial list of 51 biotechnologies and to reach a final consensus on the 10 most promising ones. In making their final choices, the panelists reported that they considered such criteria as the potential impact of the biotechnologies; the biotechnologies being low-cost, effective, and easily applied in rural 


\section{Other organizations also consider challenges, opportunities with biotechnology and genomics}

\section{World Health Organization}

The new study from the University of Toronto Joint Centre for Bioethics is in part intended to respond to concerns that were raised in a report issued in April 2002 by the World Health Organization (WHO). That document, entitled Genomics and World Health, highlighted the importance of genomics for improving health in developing countries and called for regular assessments of the health impacts of genomics.

Genetic research has the potential to lead to major medical advances within the coming years against such killer diseases as malaria, tuberculosis, and HIV / AIDS, potentially saving millions of lives in the developing world, according to the WHO report. Such research might allow developing countries to leapfrog decades of medical development and more quickly bring their citizens greatly improved, more-modern care.

In recent years, scientists have succeeded in sequencing the entire human genome, and researchers are also mapping the genomes of some important pathogens, disease vectors, and plants. Such research involves large-scale creation and utilization of databases through a high level of automation, thus requiring major capital investment. This has mostly limited research to the rich industrial nations.

While Brazil, China, Cuba, and India have conducted genomic research, many other developing nations are in danger of being left behind, much as happened with the computer revolution of the 1980s and 1990s. The WHO report emphasizes that genomic research will not change medical practice overnight but that both developing and developed nations must prepare themselves for this new technology and carefully explore its possibilities.

DNA research is underway on a number of projects that can improve health care in developing countries, with some activities already yielding results. Among the research projects mentioned in the WHO report are:

- a new "designer" mosquito that cannot carry the malaria parasite

- a class of antimalarial drugs with the potential to be effective against multi-drug-resistant parasites, as well as being inexpensive and stable
- two new types of vaccines against tuberculosis that have been derived from genetic research

- improvements in the diagnosis of leishmaniasis and dengue fever using polymerase chain reaction techniques

- a meningitis B vaccine that was developed in Cuba, providing evidence for the potential of biotechnology efforts in developing countries

- clinical trials in Kenya and in the United Kingdom of a DNA-based AIDS vaccine candidate designed specifically for Africa

- DNA technology to produce vaccines that can be incorporated into potatoes and other vegetables and fruits, against hepatitis B, cholera, measles, and human papilloma virus, allowing the vaccines to be ingested as part of a meal

While making clear the opportunities to use genomic research to benefit developing countries, the WHO report also points out the role that ethics should play in genetic research and genetic medicine. For example, the report warns, the planned development of large-scale genetic databases offers a series of hazards and ethical issues that have not been previously encountered. The report says that there is still considerable controversy about the desirability of establishing databases of this type and that there are many ambiguities regarding access and control, with possible harm to individuals, groups, and communities.

The report is available for purchase from the WHO. The cost is Swiss francs 35 (US\$ 31.50) for persons in developed countries and Swiss francs 14 for those in developing countries. Orders should be send to: World Health Organization, Marketing and Dissemination, CH-1211 Geneva 27, Switzerland; fax: 412279148 57; telephone: 412279124 76; e-mail: bookorders@ who.int. In addition, on the WHO Web site (http:// www3.who.int/whosis/genomics/genomics_report. $\mathrm{cfm})$, it is possible to view and download for free a copy of the full report as well as just a summary of it or individual chapters from it.

\section{Partnering for Global Health Forum}

In another effort to explore how advances in biotechnology could help improve health conditions in 
the developing countries of the world, representatives from private, for-profit biotechnology firms, from government agencies, and from charitable foundations assembled in Washington, D.C., in early December 2002 for the Partnering for Global Health Forum.

The event was hosted by the Bill \& Melinda Gates Foundation and the Biotechnology Industry Organization. The Gates Foundation, which was cofounded by Bill Gates, the chairman of Microsoft Corporation, has provided more than US\$ 2.5 billion in grants for international health programs since 1994. The Biotechnology Industry Organization (BIO) is an association that represents more than 1000 biotechnology companies, academic institutions, and related organizations in the United States of America and 33 other nations.

The conference included plenary sessions featuring top global health experts, company and funder presentations, "partnering meetings," and expert panels. In the presentation sessions, biotech companies discussed critical products and technologies to address neglected diseases, and public and private organizations talked about potential funding available for biotech firms. The partnering portion of the forum consisted of prescheduled meetings between biotech companies and potential partners or funders. including:

The expert panels covered a variety of topics,

- creative financing mechanisms and incentives designed to encourage additional research and development $(R \& D)$ on new vaccines and treatments for diseases that are concentrated in developing countries
- keys to effective public-private partnerships to support the development and launch of new products addressing neglected diseases in the developing world

- what it will take to attract investors for products for diseases of public health urgency in the developing world but that do not fit the pattern of traditional pharmaceutical business development models

- issues associated with public funding to support work on neglected diseases in the developing world

- how to successfully run clinical trials in the developing world

- the relationship between intellectual property rights protection and R\&D for neglected diseases

More information on the conference is available from the event's Web site, at: http://bio.org/ globalhealth. Interested persons can also contact the $\mathrm{BIO}$ association, at: Biotechnology Industry Organization, 1225 Eye Street, N.W., Suite 400, Washington, D.C. 20005, United States of America; telephone: (202) 962-9200; fax: (202) 962-9201; e-mail: globalhealth@ bio.org.

In addition, Kaisernetwork.org, an Internet service that provides coverage and analysis of health policy news in the United States and around the world, has set up a Web page for the Forum. On that Web page, at no charge, persons can view videotapes of several of the Forum's plenary sessions and expert panels. In the near future that Web page will also have free written transcripts of sessions from the Forum. The direct link to the Web page for the Forum is: http:/ / www.kaisernetwork.org/health_cast/hcast_ index.cfm?display=detail\&hc $=724$. areas; disease burden; the feasibility of the biotechnologies; and such indirect benefits as the technologies' potential for improving the environment and increasing the income of persons in developing countries.

The JCB researchers believe that this is the first study ever that has ranked biotechnologies in order of their importance to health care worldwide. In part, the JCB study responds to some of the concerns raised in a report issued in April 2002 by the World Health Organization (WHO). Entitled Genomics and World Health, the WHO document expresses the concern that most biotechnologies are being applied to the health problems of industrialized nations and that there is a looming "genomics divide" between the North and the South (see the sidebar entitled "Other organizations also consider challenges, opportunities with biotechnology and genomics").

\section{THE TOP 10 BIOTECHNOLOGIES}

The top 10 biotechnologies identified by the panel of specialist are listed below, beginning with the ones that the experts considered to be the most important.

\section{Molecular diagnostics}

Nearly half of all deaths in developing countries are due to infectious diseases. Though affordable treatments for many of these diseases exist, treatment depends on diagnosis. Many diagnostics used in developing countries are cumbersome, time-consuming, and costly. Molecular diagnostics use tools such as the polymerase chain reaction (PCR), monoclonal antibodies, and recombinant antigens to detect the presence of infections or other 
disease conditions. Costs will have to be assessed carefully, but as these technologies come into wider use, they will become more affordable for people in developing countries, particularly if manufactured locally.

\section{Recombinant vaccines}

Vaccination has resulted in the eradication of smallpox, the imminent eradication of polio, and a reduction in the prevalence of many other infectious diseases. However, there are still major infectious diseases, including HIV/AIDS and malaria, for which an effective vaccine does not exist. Besides the need for new vaccines, many current vaccines could be improved by being made more effective, safer, and less expensive. Many kinds of recombinant vaccines can be designed by genetic engineering. In contrast to traditional vaccine design, genetic engineering allows researchers to control vaccine characteristics more precisely. Recombinant vaccines can be made safer and more effective and may also prove to be less expensive than traditional vaccines because of innovative production methods and cheaper storage.

\section{Vaccine and drug delivery}

Most vaccines and many drugs are now administered by injection. Unsafe injection practices are responsible for tens of thousands of new cases of HIV/AIDS, hepatitis B, and hepatitis C every year, and injections entail the cost of trained personnel, disposable needles, and refrigeration. Alternatives to injections could make vaccine and drug delivery safer, easier to administer, and potentially less expensive. Injection alternatives can also simplify complex treatment regimes that discourage patient compliance and lead in some cases to the emergence of drug-resistant strains of disease. Combination formulations and slow-release mechanisms could also lower the number of doses in a standard treatment, thereby increasing the likelihood that patients will complete their prescriptions.

\section{Bioremediation}

Contamination of water, air, and soil, largely the result of human activity, has had an undeniable impact on human health. Bioremediation and biosensing harness the ability of microbes and plants to detect and degrade pollutants, and these technologies represent a potentially cheap and sustain- able form of waste disposal. There are two main types of pollution threatening the health of human populations in the developing world: organic waste and heavy metals such as lead, mercury, and cadmium. Bacteria possess the ability to detoxify both. While plants can break down most forms of organic waste, they are generally unable to metabolize heavy metals. Plants can, however, accumulate harmful metals in their tissues, thus making them easier to collect, harvest, and even recycle. Bioremediation can be relatively low-tech and inexpensive, relying primarily on the work of native organisms already well adapted to survive in the contaminated environment. The potential of engineered organisms to rectify pollution problems is promising, but the safety of these organisms will have to be demonstrated before they are released into the environment.

\section{Sequencing pathogen genomes}

Sequencing the genomes of human pathogens generates the data for understanding the mechanisms of disease and methods for effective treatment and prevention. The genetic sequences of a disease-causing organism can be analyzed using the tools of bioinformatics to identify proteins that could play an important role in drug and vaccine discovery. In order to take full advantage of the insights contained within genetic information, pathogen genome sequencing must be a priority in global health research.

\section{Female-controlled protection against sexually transmitted infections}

The global incidence of sexually transmitted infections (STIs) is high and rising rapidly. HIV/ AIDS is now the leading cause of mortality in subSaharan Africa and the fourth-leading cause of death worldwide. Still other STIs are also common, and it has been estimated that 333 million people acquire an STI other than HIV / AIDS annually. The global burden of STIs is felt most heavily by women, but they have few means of effective protection that do not rely on their partner's consent. Biotechnology is enabling the development of a number of new forms of female-controlled protection against STIs, such as recombinant vaccines, monoclonal antibodies, and new approaches to the development of vaginal microbicides. Advances in this area could have a significant impact on women's health as well as reduce the spread of STIs among the general population. 


\section{Bioinformatics}

In less than a decade, a vast amount of biological data has been generated. Extensive DNA, RNA, and protein data on humans and infectious organisms are stored in databases that can be accessed, free of charge, from anywhere in the world over the Internet. Through the marriage of information technology and life sciences, bioinformatics provides computer-based tools to process these data into valuable information for the prevention and treatment of infectious and noncommunicable diseases. Without having to invest heavily in the technologies used to produce these data, developing countries can take advantage of existing information and apply the power of bioinformatics to local health problems.

\section{Nutritionally enriched genetically modified crops}

Malnutrition results in greater susceptibility to disease, impaired cognitive and physical development, and multiple illnesses attributed to specific nutrient deficiencies. The underlying cause of nutrient deficiency is a diet based mainly upon nutrient-poor staple foods such as rice, potatoes, corn, and cassava. The genetic modification of staple foods to enhance their nutritional value is a promising but underutilized strategy to improve global nutrition. Several enriched genetically modified (GM) crops have been developed and are undergoing evaluation. Nevertheless, the development of enriched GM crops must be accompanied by a thorough process of evaluation to ensure that these foods are safe and environmentally friendly.

\section{Recombinant drugs}

Recombinant technology involves the insertion of a gene or genes for making a therapeutic protein into an organism, such as a bacterium or virus. As the organism grows, it manufactures the new protein, which is then harvested for medical use. Today, cutting-edge research is exploring the use of transgenic goats, cows, and other mammals as living "bioreactors" as well as the use of transgenic plants for molecular "pharming." In the future, this recombinant technology could be of growing importance to the developing nations of the world. That is because many poorer nations are facing a double burden of infectious diseases and of noncommunicable diseases such as heart disease and diabetes. Noncommunicable diseases now account for $60 \%$ of all deaths in developing countries, and current trends suggest this number will reach $73 \%$ by 2020 . Affordable sources of therapeutic proteins for treating chronic diseases, such as hormones (e.g., insulin) and interferons, are therefore critical to improving global health.

\section{Combinatorial chemistry}

Combinatorial chemistry, or combichem, is a new and powerful method of drug discovery and development. Combichem has been driven by advances in genomics and molecular biology, drawing substantially from the recent explosion of drug targets identified from genome sequencing efforts. Through the discovery of compounds that interact with these targets, combichem is translating advances in genomics into real-life therapeutic solutions. Combichem, which is highly automated, operates on the principle of diversity. By rapidly generating large numbers of variations of a molecule that researchers have good reason to suspect holds therapeutic potential, combichem can produce drugs in record time. It is becoming the mainstay of drug development, replacing the much more costly and time-consuming method of investigating one compound at a time.

\section{THE NEXT STEPS}

The JCB report says that while identifying priority technologies can help guide strategy, other measures are needed to ensure that poor nations share in the benefits of biotechnology. Among the necessary steps are:

- encouraging international research into the application of biotechnology to health problems in the developing world by fostering collaborations across borders that permit the sharing of human and financial resources

- identifying the ingredients of a flourishing biotechnology industry in the developing world by studying countries that have had some success in the field

- ensuring that scientists, policymakers, and others in the developing world are familiar with the ethical, legal, social, and policy implications of biotechnology and with how other countries are taking advantage of its benefits while minimizing its risks

- considering creation of an international commission to govern the application of biotechnology

- promoting widespread public consultation to ensure that biotechnology research is consistent 
with local values and meets the needs of as many people as possible

- establishing innovative financing structures such as "ethical" investment funds and financial incentives from governments to fund promising global health applications of biotechnology

A complete copy of the biotechnologies report, in PDF format, can be downloaded for free from the JCB Web site, at: http://www.utoronto. $\mathrm{ca} / \mathrm{jcb}$ /_genomics/top10biotechnologies.pdf

\section{SINOPSIS}

Biotecnologías que son beneficiosas para la salud pública en países en desarrollo

Millones de personas en países en desarrollo mueren actualmente cada año de enfermedades que en el futuro cercano podrían prevenirse o tratarse con poco dinero y con facilidad mediante la creación y el uso de tecnologías tales como las vacunas de elaboración genética y productos nuevos que permiten diagnosticar las enfermedades infecciosas de un modo más rápido, preciso y barato. Esto, al menos, indican los resultados de un estudio divulgado en septiembre de
2002 por el Centro Conjunto de Bioética (Joint Center for Bioethics, JCB) de la Universidad de Toronto. El estudio, que se titula Top 10 Biotechnologies for Improving Health in Developing Countries, identifica las biotecnologías genómicas y de otro tipo que ejercerán el mayor efecto beneficioso sobre la salud en el mundo en el próximo decenio. Para preparar el estudio, los investigadores del JCB trabajaron con un panel de 28 especialistas del mundo entero que son expertos en materia de tecnologías genómicas y temas de salud de alcance mundial. Fueron identificadas las 10 tecnologías siguientes: pruebas diagnósticas moleculares; vacunas recombinantes; nuevos métodos de aplicación de vacunas y medicamentos; biorremediación; genomas para la secuenciación de agentes patógenos; métodos de protección contra las enfermedades de transmisión sexual que dependan de la mujer; bioinformática; hortalizas enriquecidas y modificadas genéticamente; medicamentos recombinantes; y química combinatoria. Este trabajo, además de resumir el informe del JCB, también describe brevemente otras dos iniciativas para examinar los retos y las oportunidades que ofrecen la biotecnología y el campo de la genómica para mejorar la salud internacional: un informe de la Organización Mundial de la Salud que se emitió en abril de 2002 y que se titula Genomics and World Health, y el foro Partnering for Global Health, de diciembre de 2002, que se celebró en Washington, D.C., y en el que confluyeron representantes de empresas privadas de biotecnología con fines de lucro, agencias gubernamentales y fundaciones de beneficencia.

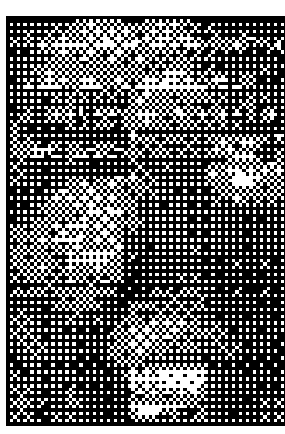

$1000,258 \mathrm{~F}$.

IBEH 90753504

Lóties: $F$

Frecio: LS\$ 22001

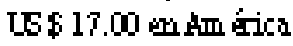
Lating lon lonte.

Dipartatestat

\section{Biodinersidad, biotechologiay desorrollo sostentble en solud $y$ agricultura conexiones entergentes}

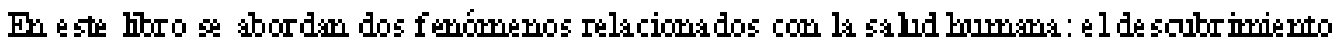
de me dicamentos y el logo de wa me jor mutric ion me diarte mejor as a g opecuarias.

Dentro de ese marco se desciben las op ciomes cientific as y tecmológicas, las perspectiras

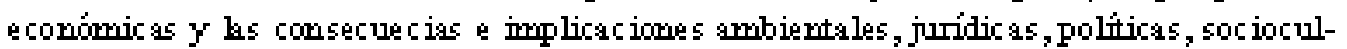
turales e insticionales que enfertan paises en diferentes etap as de desarrollo cientif iro $y$

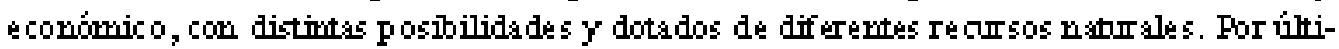

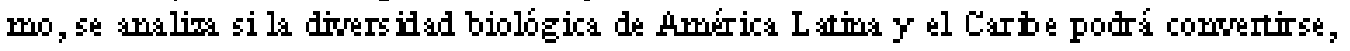
de becho, en so voriaja competitira.

Legieladores, actiristas del medio ambiente, académicos y cionificos, I epre sentartes de empresas priradas $y$ en fir todos aque los que se oryar de los productos farmacentions, la sericulenta $y$ la indust i $y$ que buesan fomas economicamente rentables de emplear la diversidad bio logica de fomma sostenible, encontration esta obra repuestas a muchos irterr ogarites.

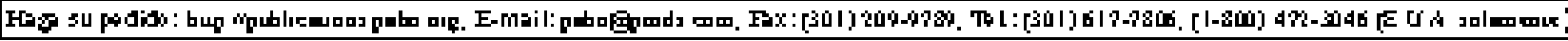

